\title{
HUBUNGAN ASUPAN NUTRISI DENGAN KEJADIAN ANEMIA PADA REMAJA PUTRI
}

\author{
Azizatul Hamidiyah \\ Program Studi D III Kebidanan, Fakultas Ilmu Kesehatan, Universitas Ibrahimy \\ Situbondo Jawa Timur \\ E-mail : azizatulhamidiyah@ibrahimy.ac.id
}

\section{Kata Kunci:}

Nutrisi, Anemia, Remaja Putri

Keywords:

Nutrition, Anemia, Young Women

Info Artikel

Tanggal dikirim: 14-12-2019

Tanggal direvisi: 15-12-2019

Tanggal diterima: 15-12-2019

DOI: $10.36341 /$ jomis.v4i1.1091

Attribution-NonCommercial 4.0

International. Some rights reserved

\begin{abstract}
ABSTRAK
Studi pendahuluan yang telah dilakukan sebelumnya di Pondok Pesantren Salafiyah Syafi'iyah Sukorejo menunjukkan bahwa mayoritas santri puteri menderita anemia sebanyak 29 dari 41 orang $(70,7 \%)$. Hal ini tentu dapat memabahayakan remaja karena dapat menyebabkan penurunan kesehatan reproduksi, terhambat perkembangan termasuk kecerdasan, menurunkan kemampuan dan konsentrasi belajar. Tujuan dari penelitian ini adalah untuk mengetahui hubungan asupan nutrisi dengan kejadian anemia pada remaja puteri di Pondok Pesantren Salafiyah Syafi'iyah Sukorejo Situbondo. Penelitian ini menggunakan penelitian kuantitaf dengan metode penelitian analitik. Pengumpulan data dilakukan dengan menggunakan recall gizi. Instrumen yang digunakan adalah lembar observasi. Analisis data dilakukan menggunakan nutri survey dan uji statistik chi-square. Populasi dalam penelitian ini adalah seluruh santri di asrama Ma'Had Aly, sampel dalam penelitian ini berjumlah 86 responden. Dari hasil penelitian menunjukkan hasil $P$-Value 0,029 dengan taraf signifikan 0,05 maka $\mathrm{H}_{0}$ ditolak, artinya ada hubungan yang signifikan antara asupan nutrisi dengan terjadinya anemia pada remaja puteri.
\end{abstract}

\begin{abstract}
Preliminary studies conducted previously at the Salafiyah Syafi'iyah Sukorejo Islamic Boarding School showed that the majority of female students suffered from anemia as many as 29 out of 41 people (70.7\%). This certainly can harm adolescents because it can cause a decrease in reproductive health, stunted development including intelligence, decreased ability and concentration of learning. The purpose of this study was to determine the relationship of nutritional intake with the incidence of anemia in young women at the Salafiyah Syafi'iyah Islamic Boarding School Sukorejo Situbondo. This research used quantitative research with analytical research methods. Data collection was performed using nutritional recall. The instrument used was an observation sheet. Data analysis was performed using a nutri survey and the chi-square statistical test. The population in this study were all santri in the Ma'Had Aly boarding school of Salafiyah Syafi' 'iyah Sukorejo boarding school, the sample in this study amounted to 86 respondents. From the results of the study showed the results of $P$-Value 0.029 with a significant level of 0.05 then $H_{0}$ was rejected, meaning that there is a significant relationship between nutritional intake and anemia in young women.
\end{abstract}

\section{PENDAHULUAN}

Anemia merupakan suatu kondisi medis dimana kadar hemoglobin kurang dari normal. Kadar $\mathrm{Hb}$ normal pada remaja puteri adalah $\geq 12$ g/dl. Remaja puteri dikatakan anemia jika kadar $\mathrm{Hb}<12 \mathrm{~g} / \mathrm{dl}$, jika anemia dibiarkan terus menerus maka akan menyebabkan kematian.
Berdasarkan data survei aktual secara global tahun 2010 diketahui bahwa prevalensi anemia pada anak usia pra sekolah, wanita hamil, dan wanita tidak hamil di dunia secara global berturutturut sebagai berikut 47,4\%, 41,8\%, dan 30,2\%, prevalensi anemia wanita tidak hamil dibenua afrika adalah 44,4\%, benua Asia $33,0 \%$, benua 
Eropa 15,2\%, benua Amerika latin dan Caribbean (LAC) $23,5 \%$, benua Amerika Utara 7,6\% dan Benua Ocenia prevelensi anemia sebesar 20,2\%.

Diperkirakan lebih dari $30 \%$ penduduk dunia atau 1500 juta orang menderita anemia dan sebagian besar tinggal di daerah tropic. Prevalensi anemia di Indonesia menurut World Health Organization (WHO) pada tahun 2007 pada wanita tidak hamil/ produtif adalah $33,1 \%$. Sedangkan menurut Herman (2008) dalam Dyah (2011) prevalensi anemia di Indonesia sebesar $57,1 \%$ diderita oleh remaja putri.

Di Indonesia prevalensi anemia pada remaja puteri tahun 2006, yaitu 28\%. Menurut WHO (2013), prevalensi anemia dunia berkisar 4088\%. Berdasarkan data hasil Riskesdas tahun 2013, prevalensi anemia di Indonesia yaitu $21,7 \%$ penderita anemia berumur 15-24 tahun sebesar 18,4\% [1]. Survey Astuti \& Rosid (2011) dalam Hamidiyah, dkk (2019) yang dilakukan kepada siswa sekolah di Indonesia menunjukkan prevalensi anemia sebesar 36\%-43\% [2]. Data Survei Kesehatan Rumah Tangga (SKRT) tahun 2004 menyatakan bahwa prevalensi anemia defisiensi pada balita $40,5 \%$, ibu nifas $45,1 \%$, remaja puteri usia $10-18$ tahun $57,1 \%$ dan usia 19 45 tahun 39,5\% di Universitas Sumatra Utara. Dari semua kelompok umur tersebut, wanita mempunyai resiko paling tinggi untuk menderita anemia terutama remaja puteri [3].

Menurut WHO (2010), angka kejadian anemia pada remaja puteri di Negara Negara berkembang sekitar 53,7\% dari semua remaja puteri, anemia sering menyerang remaja puteri disebabkan karena keadaan stress, haid, atau terlambat makan.

Menurut Merryana dkk (2012) Penyebab anemia karena kekurangan asupan nutrisi yaitu menurunnya kesehatan reproduksi, terhambatnya perkembangan motorik. Mental dan kecerdasan, menurunkan kemampuan dan konsentrasi belajar, menganggu pertumbuhan sehingga tinggi badan tidak mencapai optimal, menurunkan fisik olahraga serta tingkat kebugaran, dan mengakibatkan muka pucat.

Mayoritas remaja puteri yang ada di Pondok Pesantren Salafiyah Syafi'iyah Sukorejo Situbondo kurang memperhatikan pola makan, kebanyakan makanan yang di konsumsi adalah yang praktis dan tidak memperhatikan jenis-jenis makanan tersebut.

Berdasarkan studi pendahuluan yang dilakukan pada mahasiswa kebidanan di Asrama
Ma'had Aly Pondok Pesantren Salafiyah Syafi'iyah, yaitu 41 santri putri yang melakukan cek $\mathrm{Hb}$ didapatkan hasil 29 orang menderita anemia, sedangkan yang tidak anemia sebanyak 12 orang.

Berdasarkan data yang telah diuraikan tersebut maka dilakukan penelitian tentang Hubungan Asupan Nutrisi dengan terjadinya Anemia pada Remaja Puteri di Asrama Ma'had Aly Pondok Pesantren Salafiyah Syafi'iyah Sukorejo Situbondo. Yang mana bertujuan untuk mengidentifikasi Anemia pada Remaja Puteri di Pondok Pesantren Salafiyah Syafi'iyah Sukorejo Situbondo, mengidentifikasi Asupan Nutrisi pada Remaja Puteri di Pondok Pesantren Salafiyah Syafi'iyah Sukorejo Situbondo, dan mengetahui Hubungan Asupan Nutrisi dengan terjadinya Anemia pada Remaja Puteri di Pondok Pesantren.

\section{TINJAUAN PUSTAKA}

Menurut Hardiansyah dkk (2017) anemia adalah suatu keadaan kekurangan kadar hemoglobin $(\mathrm{Hb})$ dalam darah yang terutama disebabkan oleh kekurangan zat gizi (khususnya zat besi) yang diperlukan untuk membentuk Hb. Anemia bukan percerminan keadaan suatu penyakit atau gangguan fungsi tubuh. Secara fisiologis, anemia terjadi apabila terdapat kekurangan jumlah hemoglobin untuk mengangkut oksigen ke jaringan. Pada pria, hemoglobin normal adalah 14-18 gr \% dan eritrosit 4,5-5,5 jt/mm $\mathrm{mm}^{3}$. Sedangkan pada perempuan, hemoglobin normal 12-16 gr \% dengan eritrosit $3,5-4,5 \mathrm{jt} / \mathrm{mm}^{3}$.

Remaja puteri lebih rentan anemia dibandingkan dengan remaja laki-laki. Itu disebabkan kebutuhan zat besi pada remaja puteri adalah 3 kali lebih besar dari pada lakilaki. Remaja puteri setiap bulan mengalami menstruasi yang secara otomatis mengeluarkan darah. Itulah sebabnya remaja puteri memerlukan zat besi untuk mengembalikan kondisi tubuhnya kekeadaan semula. Yang sangat disayangkan adalah kebanyakan dari remaja puteri tidak menyadarinya. Bahkan ketika tahu pun masih menganggap anemia masalah sepele.

Kekurangan zat besi dalam menu makanan sehari-hari dapat menimbulkan anemia gizi atau yang dikenal masyarakat sebagai penyakit kurang darah. 
Keanekaragaman konsumsi makanan sangat penting dalam membantu meningkatkan Fe. Kehadiran protein hewani, vitamin C, Vitamin A, Zink (Zn), asam folat, zat gizi mikro lain dapat meningkatkan penyerapan zat besi dalam tubuh. Manfaat lain mengkonsumsi makanan sumber zat besi adalah terpenuhinya kecukupan vitamin A. Makanan sumber zat besi umumnya merupakan sumber vitamn A. Fe dari bahan makanan hewani (heme) lebih mudah diserap dari pada Fe dari bahan makanan nabati (non heme) yaitu 20-30\% dibanding hanya $2-10 \%$ saja untuk sumber dari sayuran.

Beberapa faktor penyebab kurangnya konsumsi zat besi pada remaja adalah ketersediaan pangan, kurangnya pengetahuan dan kebiasaan makan yang salah. Kebutuhan Fe remaja puteri adalah $26 \mathrm{mg}$ perhari. Asupan protein sebanyak $96,7 \%$ subyek mengkonsumsi $\geq 50$ gram untuk usia 10-12 tahun dan $\geq 57$ gram untuk usia 13-15 tahun. Protein berperan penting dalam transportasi zat besi dalam tubuh. Kurangnya asupan protein akan mengakibatkan transportasi zat besi terhambat sehingga akan terjadi defisiensi besi. Absorpsi besi yang terjadi di usus halus dibantu oleh alat angkut protein yaitu transferin dan feritin. Transferin mengandung besi ferros yang berfungsi mentranspor besi ke sum-sum tulang untuk pembentukan hemoglobin. Asupan vitamin $\mathrm{C}$ sebanyak $95,6 \%$ subyek mengkonsumsi $\geq 50 \mathrm{mg}$ usia 10 12 tahun dan $\geq 75 \mathrm{mg}$ usia 16-25 tahun. Sumber vitamin $\mathrm{C}$ yang banyak dikonsumsi siswi seperti jeruk, apel, mangga, pisang. Vitamin $\mathrm{C}$ berfungsi mempercepat penyerapan zat besi. Asupan vitamin B12 sebanyak 81,1\% subyek mengkonsumsi $\geq 1,8$ ug untuk usia 10 12 tahun dan $\geq 2,4$ ug untuk usia 13-15 tahun. Sumber vitamin B12 yang banyak dikonsumsi subyek adalah telur dan susu. Asupan folat sebanyak $53,3 \%$ subyek mengkonsumsi $\geq 300$ ug untuk usia 10-12 tahun. Sumber folat yang banyak di konsumsi subyek seperti sayur bayam, hati, buah, kacang termasuk dalam kategori cukup. Vitamin B12 dan asam folat penting untuk sintesis DNA. Apalagi kekurangan salah satu diantaranya dapat mempengaruhi regenerasi seluler dan menyebabkan terjadinya anemia makrositik, dimana ukuran sel-sel darah merah lebih besar dari normal. Usia 19-50 tahun membutuhkan $700 \mathrm{mg}$ fosfor, seseorang yang kekurangan fosfor akan menyebabkan penyakit seperti tulang lemah dan patah tulang, osteoporosis, perubahan selera, nyeri sendi dan otot, masalah berolahraga, kerusakan gigi, mati rasa dan kesemutan, kecemasan, masalah berat badan, kesulitan berkonsentrasi, pertumbuhan terhambat dan masalah-masalah pengembangan lainnya. Usia 16-80 Tahun membutuhkan $14 \mathrm{mg}$ zinc, zinc dikenal sebagai sebuah logam transisi yang masih masuk kedalam golongan 12 pada tabel periodik dan kita lebih mengetahuinya sebagai seng dengan simbol $\mathrm{Zn}$. Bagi hewan dan tanaman, zinc ini mempunyai arti biologis yang cukup substansial. Ada beberapa fungsi yang berada di bawah tangung jawab zinc dalam mendukung kinerja setiap tubuh manusia, dan salah satunya adalah memberikan rangsangan aktivitas sekitar 100 enzim yang tidaklah sama satu dengan yang lain.

Senyawa satu ini adalah mineral yang penting dan tidak dapat dilewatkan oleh tubuh karena organ tubuh kita tentu sangat membutuhkannya, contohnya adalah otot, kulit serta rambut dan juga organ lainnya. Supaya performa dan fungsi tubuh berjalan normal, zinc adalah salah satu zat yang wajib untuk di penuhi menurut kebutuhan harian yang semestinya menurut usia dan jenis kelamin seseorang. Zinc ini termasuk senyawa yang membentuk beberapa organ tubuh maka tentu asupannya perlu di jaga dengan baik. Usia 19 tahun keatas membutuhkan $1,1 \mathrm{mg}$ vitamin B1, vitamin B1 atau tiamin adalah salah satu vitamin yang berguna dalam merubah karbohidrat menjadi energy untuk tubuh, terutama otak dan system syaraf. Vitamin B1 dapat dijumpai dalam berbagai makanan, seperti sereal, daging sapi, kacang-kacangan dan telur.

Hemoglobin terbentuk dari 4 molekul protein (rantai globulin) yang terhubung satu sama lain. Molekul hemoglobin dewasa normal mengandung dua rantai alpha-globulin dan dua rantai beta-globulin. Pada janin yang 
baru lahir, rantai beta tidak umum dan molekul hemoglobin terbentuk dari dua rantai alpha dan dua rantai gamma. Seiring dengan tumbuhnya bayi, rantai gamma secara berangsur di gantikan dengan rantai beta membentuk struktur hemoglobin dewasa.

Masing-masing rantai globulin mengandung senyawa penting porphyrin yang mengandung zat besi yang diketahui heme. Senyawa heme mengandung atom besi yang berperan vital yang mengangkut oksigen dan karbon dioksida dalam darah. Hemoglobin yang mengandung zat besi juga berperan dalam memberi warna merah dalam darah.

Tugas utama dari hemoglobin adalah sebagai pengangkut oksigen (O2) dari paruparu atau insang keseluruh jaringan badan [4]. Selain berperan penting dalam pengangkutan O2, hemoglobin juga ikut serta dalam pengangkutan $\mathrm{CO} 2$ dan menentukan kapasitas penyanggah dari darah [5]. Darah orang normal mengandung hemoglobin hampir 15 gram dalam tiap-tiap $100 \mathrm{ml}$ darah dan tiap hemoglobin dapat berikatan dengan oksigen maksimal kira-kira 1,34 ml [6].

Hasil penelitian yang dilakukan oleh Gunatmaningsih (2007), meneliti tentang faktor-faktor yang berhubungan dengan kejadian anemia pada remaja puteri di SMA negeri 1 kecamatan jati barang kabupaten brebes dengan hasil penelitian yaitu asupan nutrisi menjadi faktor penyebab anemia $(\mathrm{P}=0,002)$. Hasil penelitian ini juga didukung oleh penelitian yang dilakukan oleh Septriyanti (2015), meneliti tentang hubungan asupan nutrisi dengan kejadian anemia pada siswa kelas X di SMK muhammadiyah 2 bejen bantul yogyakarta dengan hasil penelitian yaitu ada hubungan asupan nutrisi terhadap kejadian anemia $(\mathrm{P}=0,000)$. Hasil penelitian ini juga didukung oleh penelitian yang dilakukan oleh Rosi Holida (2017), meneliti tentang hubungan asupan nutrisi dengan terjadinya anemia pada remaja puteri tunagrahita dringan di SLB negeri 1 bantul yogyakarta dengan hasil penelitian yaitu ada hubungan asupan nutrisi terhadap kejadian anemia $(\mathrm{P}=0,001)$.

\section{METODE}

Penelitian ini menggunakan penelitian kuantitatif dengan metode penelitian analitik Populasi dalam penelitian ini adalah seluruh santri putri di asrama Ma'had 'Aly di Pondok Pesantren Salafiyah Syafi'iyah sebanyak 636 responden. Sampel dalam penelitian sebanyak 86 responden, pada penelitian ini dapat dilakukan dengan menggunakan lembar observasi di Asrama Ma'had Aly Puteri Pondok Pesantren Salafiyah Syafi'iyah Sukorejo Situbondo. Lembar observasi berisi list makanan dan minuman yang dikonsumsi selama 7 hari terakhir beserta dengan takaran rumah tangga. Kemudian peneliti mengkonversi takaran rumah tangga tersebut kedalam satuan gram. Berikutnya semua isian yang telah dikonversi ke dalam satuan gram diinput dalam aplikasi nutrisurvey untuk melihat rata-rata takaran $\mathrm{Fe}$, protein, dan lain-lain dalam makanan dan minuman selama 7 hari terakhir per masing-masing responden, kemudian dikategorikan dalam asupan makanan. Untuk pengukuran anemia dilakukan dengan menggunakan $\mathrm{Hb}$ check, analisis data disini menggunakan analisis univariat dan analisis bivariat menggunakan uji statistik chi kuadrat (X2).

\section{HASIL DAN PEMBAHASAN \\ Data Univariat}

Karakteristik responden berdasarkan pendidikan disajikan pada tabel 1 .

Tabel 1 Distribusi Frekuensi Responden berdasarkan Pendidikan di Asrama Ma'had Aly Puteri Pondok Pesantren Salafiyah Syafi'iyah Sukorejo Situbondo

\begin{tabular}{ccc}
\hline Pendidikan & Frekuensi & \% \\
\hline SMP & 2 & 2,4 \\
SMA & 37 & 43,0 \\
PT & 47 & 54,6 \\
Total & 86 & 100 \\
\hline
\end{tabular}

Berdasarkan Tabel 1 menunjukkan bahwa dari 86 responden sebagian besar yaitu 47 remaja $(54,6 \%)$ berpendidikan PT, sedangkan sebagian kecil yaitu 2 remaja $(2,4 \%)$ berpendidikan SMP.

Karakteristik responden berdasarkan usia disajikan pada tabel 2 
Tabel 2 Distribusi Frekuensi Responden berdasarkan Usia di Asrama Ma'had Aly Puteri Pondok Pesantren Salafiyah Syafi'iyah Sukorejo Situbondo

\begin{tabular}{ccc}
\hline Usia & Frekuensi & \% \\
\hline $15-18$ & 39 & 45,4 \\
$19-24$ & 47 & 54,6 \\
Total & 86 & 100 \\
\hline
\end{tabular}

Berdasarkan tabel 5.2 distribusi usia 20 tahun responden dengan persentase tertinggi sebesar $27,9 \%$ (24 orang) dan persentase erendah pada usia 15 tahun sebesar 2,4\% (2 orang).

\section{Anemia}

Menurut Hardiansyah dkk (2017), anemia adalah suatu keadaan kekurangan kadar hemoglobin $(\mathrm{Hb})$ dalam darah yang terutama disebabkan oleh kekurangan zat gizi (khususnya zat besi) yang diperlukan untuk membentuk $\mathrm{Hb}$. Kadar $\mathrm{Hb}$ normal pada remaja putri adalah $12 \mathrm{gr} / \mathrm{dl}$. Remaja putri dikatakan anemia jika kadar $\mathrm{Hb}<12$ gr/dl (Proverawati 2011).

Remaja puteri lebih rentan anemia dibandingkan dengan remaja laki-laki. Itu disebabkan kebutuhan zat besi pada remaja puteri adalah 3 kali lebih besar dari pada lakilaki. Remaja puteri setiap bulan mengalami menstruasi yang secara otomatis mengeluarkan darah. Itulah sebabnya remaja puteri memerlukan zat besi untuk mengembalikan kondisi tubuhnya kekeadaan semula.

Distribusi frekwensi anemia pada santri di asrama Ma'had Aly puteri Pondok Pesantren Salafiyah Syafi'iyah Sukorejo Situbondo disajikan pada tabel 3.

Tabel 3 Ditribusi Frekuensi Anemia pada Santri di Asrama Ma'had Aly puteri Pondok Pesantren Salafiyah Syafi'iyah Sukorejo Situbondo

\begin{tabular}{ccc}
\hline Status & Frekuensi & \% \\
\hline Anemia & 59 & 68,6 \\
Tidak anemia & 27 & 31,4 \\
Total & 86 & 100 \\
\hline
\end{tabular}

Tabel 3 menunjukkan bahwa dari 86 responden sebagian besar yaitu 59 remaja puteri $(68,6 \%)$ mengalami anemia.
Remaja puteri beresiko sepuluh kali untuk menderita anemia, selain ketidak seimbangan asupan nutrisi, faktor pertumbuhan, juga adanya siklus menstruasi bulanan yang menyebabkan remaja puteri membutuhkan asupan $\mathrm{Fe}$ lebih banyak. Kebiasaan mengkonsumsi makanan juga menjadi faktor penyebab Anemia pada remaja puteri. Hal tersebut bisa membahayakan penderita seperti, adanya masalah pada ginjal atau inflamasi arthritis, tiroid yang kurang aktif, depresi atau kehilangan memori/ demensia, jika anemia dibiarkan begitu saja tanpa ditangani hal tersebut bisa mengancam jiwa penderita.

\section{Asupan Nutrisi}

Menurut Supariasa (2001), nutrisi adalah suatu proses organisme menggunakan makanan yang dikonsumsi secara normal melalui proses degesti, absorbsi, transportasi, penyimpanan, metabolisme dan pengeluaran zat-zat yang tidak digunakan untuk mempertahankan kehidupan, pertumbuhan, danfungsi normal dari organ-organ, serta menghasilkan energi. Sebelum masa remaja, kebutuhan nutrisi anak lelaki dan anak perempuan tidak dibedakan, tetapi pada masa remaja terjadi perubahan biologic dan fisiologik tubuh yang spesifik sesuai gender (gender spesific) sehingga kebutuhan nutrisipun menjadi berlainan. Sebagai contoh, remaja perempuan membutuhkan zat besi lebih banyak karena mengalami menstruasi setiap bulan.

Karakteristik responden berdasarkan Asupan Nutrisi disajikan pada tabel 4.

Tabel 4 Distribusi frekuensi Asupan Nutrisi pada Santri di Asrama Ma'had Aly Pondok Pesantren Salafiyah Syafi'iyah Sukorejo Situbondo

\begin{tabular}{ccc}
\hline $\begin{array}{c}\text { Asupan } \\
\text { Nutrisi }\end{array}$ & Frekuensi & $\%$ \\
\hline Kurang & 79 & 91,9 \\
Cukup & 7 & 8,1 \\
Total & 86 & 100 \\
\hline
\end{tabular}

Tabel 4 menunjukkan bahwa dari 86 responden sebagian besar yaitu 79 remaja $(91,9 \%)$ asupan nutrisinya kurang. Rata-rata dari asupan nutrisi yang terdiri dari Fe 13,03 
$\mathrm{mg}$, protein 57,58 gr, vit.c 49,02 $\mathrm{mg}$, zinc 6,40 $\mathrm{mg}$, vit. B1 $0,65 \mathrm{mg}$. Sedangkan standar normal harian dari asupan nutrisi tersebut adalah fe $\geq 15 \mathrm{mg}$, protein $\geq 57$ gr, vit. $\mathrm{C} \geq 65$ $\mathrm{mg}$, zinc $\geq 24 \mathrm{mg}$, vit. B1 $\geq 1,1 \mathrm{mg}$.

Hal ini disebabkan karena Kurangnya tingkat asupan zat gizi responden antara lain dipengaruhi oleh kebiasaan makan yang melewatkan satu maupun dua waktu makan. Rata - rata responden memiliki pola konsumsi makanan pokok $2 \mathrm{x}$ sehari dan menggantinya dengan kebiasaan mengkonsumsi makanan selingan serta makanan yang disediakan juga terbatas. Remaja putri pada umumnya memiliki kebiasaan makan tidak sehat, antara lain tidak makan pagi disebabkan oleh kegiatan ponpes yang terlalu padat, kebiasaan ngemil makanan rendah gizi dan makanan siap saji, dalam jangka waktu lama akan menyebabkan anemia.

\section{Analisis Bivariat}

Nutrisi menurut Rock CL (2004) adalah proses dimana tubuh manusia menggunakan makanan untuk membentu kenergi, mempertahankan kesehatan, pertumbuhan dan untuk berlangsungnya fungsi normal setiap organ baik antara asupan nutrisi dengan kebutuhan nutrisi. Sedangkan menurut Supariasa (2001), nutrisi adalah suatu proses organisme menggunakan makanan yang dikonsumsi secara normal melalui proses degesti, absorbsi, transportasi, penyimpanan, metabolisme dan pengeluaran zat-zat yang tidak digunakan untuk mempertahankan kehidupan, pertumbuhan, danfungsi normal dari organ-organ, serta menghasilkan energi. Dalam penelitian ini, peneliti mengukur dari segi Fe, Protein, Vitamin C, Zinc, Vitamin B1. Berdasarkan jumlah yang dibutuhkan oleh tubuh, zat gizi terbagi menjadi dua golongan yaitu zat gizi makro yang terdiri dari karbohidrat, lemakdan protein, serta zat gizi mikroya itu mineral dan vitamin. Asupan zat gizi remaja dipengaruhi oleh kebiasaan makan dan pola konsumsinya. Kebiasaan makan remaja sendiri akan berdampak pada kesehatannya diperiode kehidupan selanjutnya.

Anemia adalah suatu kondisi medis dimana sel darah merah atau hemoglobin kurang dari normal. Kadar $\mathrm{Hb}$ normal pada remaja putri adalah $12 \mathrm{gr} / \mathrm{dl}$. Remaja putri dikatakan anemia jika kadar $\mathrm{Hb}<12$ gr/dl [7].

Analisis hubungan asupan nutrisi dengan kejadian anemia dalam penelitian ini sebagaimana pada tabel 5

Tabel 5 Distribusi Silang Berdasarkan jumlah hubungan asupan nutrisi dengan terjadinya anemia pada remaja puteri di Asrama Ma'had Aly Pondok Pesantren Salafiyah Syafi'iyah Sukorejo Situbondo

\begin{tabular}{|c|c|c|c|c|c|c|c|}
\hline \multirow{3}{*}{ Anemia } & \multicolumn{4}{|c|}{ Asupan Nutrisi } & \multirow{2}{*}{\multicolumn{2}{|c|}{ Total }} & \multirow{3}{*}{ P-value } \\
\hline & \multicolumn{2}{|c|}{ Kurang } & \multicolumn{2}{|c|}{ Cukup } & & & \\
\hline & $\mathbf{F}$ & $\%$ & $\mathbf{F}$ & $\%$ & $\mathbf{F}$ & $\%$ & \\
\hline Anemi & 57 & 066 & 0 & & 59 & 100 & \\
\hline Tidak Anemia & & & & & 27 & 100 & 0070 \\
\hline Totol & 22 & 81,5 & 5 & 18,5 & & 100 & \\
\hline Totat & 79 & 91,9 & 7 & 8,1 & 00 & 100 & \\
\hline
\end{tabular}

Dari tabel 5 dapat diketahui bahwa dari 86 santri puteri di Ma'had Aly yang mengalami anemia sebanyak 57 orang $(72,1 \%)$ artinya lebih banyak santri yang masih anemi disebabkan karena kurangnya asupan nutrisi.

Berdasarkan hasil analisis data menggunakan chi-square diperoleh p-value sebesar 0,029 dengan taraf signifikan 0,05. Karena $\mathrm{p}$-value $<$ a maka $\mathrm{H}_{0}$ ditolak artinya ada hubungan yang signifikan antara asupan nutrisi dengan terjadinya anemia pada remaja puteri di asrama Ma'had Aly Pondok pesantren Salafiyah Syafi'iyah Sukorejo Situbondo.

Hasil penelitian ini didukung oleh penelitian yang dilakukan oleh Gunatmaningsih (2007), meneliti tentang faktor-faktor yang berhubungan dengan kejadian anemia pada remaja puteri di SMA 
negeri 1 kecamatan jati barang kabupaten brebes dengan hasil penelitian yaitu asupan nutrisi menjadi faktor penyebab anemia $(\mathrm{P}=0,002)$. Hasil penelitian ini juga didukung oleh penelitian yang dilakukan oleh Septriyanti (2015), meneliti tentang hubungan asupan nutrisi dengan kejadian anemia pada siswa kelas X di SMK muhammadiyah 2 bejen bantul yogyakarta dengan hasil penelitian yaitu ada hubungan asupan nutrisi terhadap kejadian anemia $(\mathrm{P}=0,000)$. Hasil penelitian ini juga didukung oleh penelitian yang dilakukan oleh Rosi Holida (2017), meneliti tentang hubungan asupan nutrisi dengan terjadinya anemia pada remaja puteri tunagrahita dringan di SLB negeri 1 bantul yogyakarta dengan hasil penelitian yaitu ada hubungan asupan nutrisi terhadap kejadian anemia $(\mathrm{P}=0,001)$.

Hal ini disebabkan karena kurangnya tingkat asupan zat gizi responden antara lain dipengaruhi oleh kebiasaan makan yang melewatkan satu maupun dua waktu makan. Rata - rata responden memiliki pola konsumsi makanan pokok $2 \mathrm{x}$ sehari dan menggantinya dengan kebiasaan mengkonsumsi makanan selingan serta makanan yang disediakan juga terbatas. Remaja puteri pada umumnya memiliki kebiasaan makan tidak sehat, antara lain tidak makan pagi, kebiasaan ngemil makanan rendah gizi dan makanan siap saji, dalam jangka waktu lama akan menyebabkan anemia. Makanan yang dikonsumsi merupakan gambaran dari berbagai faktor diantaranya kebiasaan makan keluarga, teman sebaya dan adanya iklan pada media sosial serta ketersediaan pangan. Kebutuhan zat besi remaja akan menurun seiring dengan melambatnya pertumbuhan setelah pubertas. Makanan yang banyak mengandung zat besi adalah: hati, daging merah, daging putih, yang disebut sumber besi heme dan kacangkacangan serta sayuran hijau yang dikenal dengan sumber besi non heme.

Bagi remaja khususnya remaja puteri bagusnya mengkonsumsi makanan seperti yang disebutkan diatas untuk mencegah terjadinya anemia. Berdasarkan tabel 5 tidak semua asupan nutrisi yang kurang mengalami kejadian anemia, terdapat $22(28 \%)$ responden yang mengalami tidak anemia dengan asupan nutrisi kurang. Hal ini disebabkan karena anemia tidak hanya terjadi pada asupan nutrisi tetapi juga ada faktor-faktor lain yang menyebabkan terjadinya anemia seperti istirahat yang cukup, sering berolahraga dan menstruasi yang terjadi setiap bulan.

\section{KESIMPULAN}

Simpulan penelitian ini menujukkan ada hubungan asupan nutrisi dengan terjadinya anemia pada remaja puteri di Asrama Ma'had Aly Pondok Pesantren Salafiyah Syafi'iyah Sukorejo Banyuputih Situbondo dengan p-value sebesar 0,029 dengan taraf signifikan 0,05.

Saran penelitian ini yaitu bagi peneliti selanjutnya, perlu diteliti lebih lanjut upaya yang bisa menigkatkan kadar asupan nutrisi $\mathrm{Fe}$ dan factor-faktor lain yang berhubungan dengan anemia, seperti olahraga yang cukup, pola istirahat, dan upaya makanan tambahan untuk mennaggulangi anemia.Adanya penelitian ini diharapkan institusi pendidikan dapat mengembangkan ilmu pengetahuan dalam hal asupan nutrisi serta memberikan fasilitas yang cukup terutama pada referensi tentang kebutuhan zat besi pada asupan nutrisi yang terbaru, bagi Pondok Pesantren Salafiyah Syafi'iyah Sukorejo Situbondo diharapkan memberikan edukasi kepada santri tentang pentingnya mengatur asupan nutrisi dan mengatur menu dagangan penjual nasi yang ada sehingga mereka juga faham kebutuhan asupan nutrisi tersebut.

\section{DAFTAR PUSTAKA}

[1] Kementrian Kesehatan RI, Riset Kesehatan Dasar Nasional, Jakarta: Kementrian Kesehatan RI, 2013.

[2] A. Hamidiyah, L. Fitria and D. A. Ningsih, "Pengaruh Fortifikasi Nugget Moringa Oleifera Terhadap Peningkatan Kadar Hemoglobin," OKSITOSIN: Jurnal Ilmiah Kebidanan, vol. 6, no. 2, pp. 135142, 2019.

[3] Departeman Gizi dan Kesehatan Masyarakat FKM UI, Gizi Dan Kesehatan Masyarakat, Jakarta: PT. Rajagrfindo Persada, 2007.

[4] N. A. Campbell, Biologi. Edisi Kelima Jilid 3, Jakarta : Erlangga, 2004. 
[5] L. Sherwoord, Fisiologi Manusia dari Sel ke Sistem. Alih Bahasa:Brahm U., Jakarta: EGC, 2001.

[6] B. Fikri and Gando, Transport Oksigen, Makassar : Universitas Hasanuddin, 2005.

[7] A. Proverawati, Buku Anemia dan Anemia Kehamilan, Yogyakarta: Nuha Medika, 2013.

[8] M. Andriani, Pengantar Gizi Masyarakat, Jakarta: Kencana Prenada Media Grup, 2012.

[9] S. Almatsier, Gizi Seimbang Dalam Daur Kehidupan, Jakarta: Gramedia Pustaka Utama, 2011.

[10] P. Djoko, Panduan Gizi Lengkap Keluarga dan Olahragawan, Yogyakarta: ANDI OFFSET, 2007. 